\title{
VITAIRAT AZ EURÓPAI KÖZIGAZGATÁSI TÉRSÉGRŐL
}

\section{Torma András}

\section{BEVEZETÉS}

Az uniós intézmények és a tagállamok közigazgatási hatóságai közötti, rendkívül bonyolult kapcsolatrendszer ma már - az Európai Gazdasági Térséghez hasonlóan - egyetlen térben zajlik, amit a szakirodalom European Administrative Space - Európai Közigazgatási Térségnek (a továbbiakban: EKT) nevezettel.Ajelen tanulmány-egyfajta vitairatként, vagyis helyenként kérdőjeleket elhelyezve - ennek a Térségnek a fogalmát, kialakulását, fő jellemzőit, valamint jövőjét igyekszik felvázolni, a rendelkezésre álló, korlátozott keretek között.

\section{Az Európai Közigazgatási Térség fogalma}

Az Európai Szén - és Acél Közösséget létrehozó Párizsi Szerződés 1951ben történt megkötése óta eltelt majd' hét évtizedben megvalósulteurópai integráció magával hozta a tagállamok nemzeti adminisztrációinak egyfajta konvergenciáját, egymáshoz-közeledését. Különösen funkcionális és értékorientációs szempontból, de szervezeti és eljárási szempontból is. Ma már nem vitatható, hogy nem csak európai (uniós) jogról, európai (uniós) környezetjogról,európai büntetőjogról stb., hanem európai közigazgatásról, illetve európai közigazgatási jogról is beszélhetünk. Az uniós jog végrehajtásának és érvényesülésének záloga ugyanis a hatékony és lojális együttmüködés az uniós intézmények és a tagállami hatóságok között, másfelől pedig az egyes tagállamok azonos feladatkörü közigazgatási hatóságai között. A több évtizedes közösségi/uniós együttmüködés nyilvánvalóan kialakított egyfajta európai közigazgatási kultúrát, illetve értékrendet, amelyet ma már több szerző az acquis communautaire (a közösségi vívmányok) részének tekint. ${ }^{1}$

Az Európai Közigazgatási Térség elméleti értelemben nem más, mint az Európai Unió intézményei és a tagállamok közigazgatási szervei által, az uniós jog megalkotása és alkalmazása révén megvalósított, illetve megvalósuló egyfajta harmonizált értékszintézis. ${ }^{2}$ Úgy is fogalmazhatunk, hogy az EKT az acquis communautaire speciális része. Tulajdonképpen

\footnotetext{
1 Például : Jürgen Schwarze, Eberhard Schmidt-Assmann, Sabino Cassese, Czuczai Jenő, Balázs István, stb.

2 Czuczai Jenő. Közigazgatás és európai integráció. Magyar Közigazgatási Jog Különös Rész / L. Ficzere, I. Forgács (szerk.). Budapest : Osiris Kiadó, 1999. 446. o.
} 
egy metafora, amely komoly gyakorlati következményekkel járt és jár az uniós tagságra pályázó országok számára. Olyan kritériumként jeleníti meg az európai közigazgatási elveket, amelyeket a tagjelölt államoknak figyelembe kell venniük. Ha ugyanis nem veszik figyelembe, illetve nem alkalmazzák ezeket az Európai Bíróság által, a tagállamok jogrendszereiből kiemelt és általánosan érvényesülő jogelveket, akkor nem képesek az acquis communautaire követelményeit érvényesíteni. ${ }^{3}$ Ez pedig kizárja a csatlakozás lehetőségét, hiszen azt bizonyítja, hogy a tagjelölt állam közigazgatásának színvonala nem éri el az uniós tagsághoz szükséges színvonalat. (A közigazgatási elvekre később még visszatérünk!).

Tény, hogy az uniós intézményeknek ma sincsenek a tagállamokba telepített saját végrehajtó szervei, másfelől pedig a közösségi vívmányokon belül - tárgyi jogi értelemben - még ma sem beszélhetünk közigazgatási jogról. Mindez azonban korántsem jelenti azt, hogy az elmúlt évtizedekben nem fogalmazódtak meg a tagállamok közigazgatási szerveivel, eljárásaival és személyzetével kapcsolatos közösségi/uniós követelmények, illetve elvárások. Ezeket nevezhetjük európai közigazgatási értékeknek is, hiszen alapvetően határozzák meg annak a fokozatosan kialakuló, egységesülő Európai Közigazgatási Térségnek a szervezeti és múködési elveit, amely az Európai Unió jogrendszere érvényesülésének egyik fontos garanciája. ${ }^{4}$

Világos tehát, hogy a fentiekben megadott EKT - fogalom mára szélesebb értelmet kapott, hiszen több mint tizenöt éve túl vagyunk az Unió legnagyobb, ún. keleti kibővítésén, amikor tíz tagjelölt állam csatlakozott. Éppen ezért az EKT ma már sokkal több, mint valamiféle csatlakozási feltétel, bár kétségtelen, hogy az is, hiszen tagjelölt államok most is vannak (például: Törökország, Szerbia, Albánia stb.). Csakhogy látni kell: az európai integráció nem egy állapot, hanem egy fejlödö folyamat. Nyilvánvalóan más - és más volt a tagállamok közigazgatási színvonalának konvergenciaszintje a déli kibővítés idején (1981-ben, amikor Görögország, és 1986-ban, amikor Spanyolország és Portugália csatlakozott), az 1995-ös kibővítéskor (mikor Ausztria, Svédország és Finnország csatlakozott), mint a 2004 évi keleti kibővítéskor. A tagjelölt országoknak éppen ezért arra kell törekedniük napjainkban is, hogy az uniós tagállamok közigazgatásának átlagos szintjét érjék el. Az összehasonlítás alapját a csatlakozni kívánó ország és a tagállamok közigazgatási színvonalának átlaga kell, hogy képezze. ${ }^{5}$

3 Józsa Z. Az európai közigazgatási tér összefüggéseiről. Magyar Közigazgatás. 2003. № 12. 724, 725. o.

4 D’Orta C. What for the European Administrative Space? Maastricht : EIPA, 2003.

5 OECD SIGMA/PUMA. European Principles for Public Administration. SIGMA Paper. 1999. № 27. 15. o. 
A 2007-ben megkötött és 2009-ben hatályba lépett Lisszaboni Szerzödés utáni tíz év alatt,az EKTegy olyan értékszintézis lett, amely általánosan jellemzi az Európai Unió és a tagállamok nemzeti közigazgatásai közötti bonyolult kapcsolatrendszert is. ${ }^{6}$ A konvergencia szint tehát jelentősen emelkedett az utóbbi években, hiszen az uniós jog hatékony érvényesítése ezt követelte meg. Ennek következtében 2000 után az EKT már nem huszonnyolc, illetve az Egyesült Királyság kilépésétől (Brexit) huszonhét féle közigazgatási apparátus valamiféle széttöredezett egysége, hanem sokkal inkább egy olyan térség, amelyen az uniós és a tagállami hatóságok lojálisan együttmüködnek, és szervezet-hálózatként, egymással „összeölelkezve", együttesen gondoskodnak az uniós jog érvényesítéséről. ${ }^{7}$ Vagy ahogyan egy másik szerző fogalmaz: " $<\ldots>$ funkcionális értelemben az európai közigazgatás a hatalmi ágak szétválasztásának az együttmüködés, és az alá-fölé rendeltség közötti útjaként jellemezhetö". ${ }^{8}$ Nem kétséges, hogy ma, 2020-ban, már ezért beszélhetünk európai közigazgatásról és európai közigazgatási jogról!

\section{Az Európai Közigazgatási Térség kialakulása}

Az Európai Közigazgatási Intézetben (EIPA - Maastricht), valamint a Firenzei Egyetem Európai Intézetében folytatott kutatások eredményei, a csatlakozási feltételeket rögzítő „Koppenhágai kritériumok” megfogalmazása, valamint az Amszterdami Szerződés (1997) révén, az Európai Unió jelentős lépést tett egy egységesEurópai Közigazgatási Térség kialakítása felé. Ebben fontos szerepet játszott a Strasbourg székhellyel müködő Európa Tanács, valamint a párizsi székhelyü OECD és annak SIGMA programja is. Az Amszterdami Szerződés megkötését (1997) követő mintegy másfél évtizedben, az Európai Közigazgatási Térség kontúrjai egyre erőteljesebben rajzolódtak ki. Kissé bővebben mindezen folyamatokról:

Az 1981-ben alapított Európai Közigazgatási Intézet alapvető feladatát abban jelölték meg, hogy folyamatosan elemezze az Európai Közösségek intézményei és a tagállamok közigazgatásának kapcsolat-rendszerét. Ebben jelentős szerepet játszott az a tény, hogy a közösségi jogalkotásban egyre nagyobb jelentőségre tett szert az irányelv, mint jogforrás, amely

${ }^{6}$ A 2007-ben megkötött Lisszaboni Szerződés jelentősen módosította az Európai Unió elsődleges joganyagát. A megnevezés valójában két szerződésnek a gyűjtőfogalmaként használatos: egyik az Európai Unióról szóló Szerződés (a továbbiakban - EUSz), a másik pedig az Európai Unió Működéséről szóló Szerződés (a továbbiakban - EUMSz).

Ibanez A. A közösségi jog ellenőrzése és végrehajtása. Budapest : Osiris Kiadó, 2000. 281. o.

8 Prof. Schmidt-Assmann Eberhard. Az európai közigazgatás együttműködési és alá-fölé rendeltségi modellje. Európai Jog. 2003. № 3. 10. o. 
a tagállamok számára megfelelő mozgásteret biztosított, miközben persze általánosan kötelező volt. Az Intézetben, valamint a Firenze városában működő másik európai intézetben kibontakozott igazgatás-tudományi és empirikus összehasonlító kutatások egyik első eredményeként született meg Jürgen Schwarzeprofesszor máig meghatározó jelentőségü monográfiája az európai közigazgatási jogról. ${ }^{9}$

A “Koppenhágai kritériumok” azokat a feltételeket rögzítik, amelyeket 1993 júniusában, Koppenhágában fogalmaztak meg az EU állam - és kormányföi, az EU-hoz való csatlakozás kritériumaiként a kelet-közép európai országok számára. Ezek három ügykört fednek le, a következők szerint:

1. Stabilan müködő demokratikus intézményrendszer, amely garantálja a jogállamiság és az emberi jogok érvényesülését, valamint biztosítja a kisebbségek védelmét.

2. Müködő piacgazdaság, amely képes megbirkózni a piaci erők versenyével.

3. A tagságból fakadó kötelezettségek teljesítésére való képesség: az acquis communautaire átvétele és érvényesítése, ideértve a gazdasági és monetáris unió, valamint a politikai unió követelményeit is.

Az EKT szempontjából mindezen kritériumok megfogalmazásának azért van jelentősége, mert nyilvánvaló, hogy az EU tagállamai akkoriban (1993-ban) már megfeleltek az azok által támasztott követelményeknek. A tagjelölt országok részéről pedig a kritériumok teljesítése végül is az Európai Közigazgatási Térséghez való csatlakozás lehetőségét is jelentette és jelenti napjainkban is.

Az OECD (Párizs) 1992-ben indította útjára a SIGMA (Support for Improvement in Governance and Management in Central and Eastern European Countries - Támogatás a közép-kelet európai országok részére, az Irányítás és Menedzsment Fejlesztésére) Programját, hat volt szocialista ország (köztük Magyarország) megsegítésére. 1994-ben a programba további öt országot, később pedig országok egész sorát vontak be. A program fó feladata a rendszerváltó országok közigazgatási (kormányzati) kapacitásának bővítése, illetve annak elősegítése volt. Később, 1999-ben a programba bekapcsolódott az Európai Bizottság révén az Európai Unió is, hiszen annak Phare programja gyakorlatilag ugyan ezt célozta. A SIGMA

\footnotetext{
9 Schwarze J. Europaisches Verwaltungsrecht. Nomos Verlagsgesellschaft. Baden-Baden, 1988. A monográfia angol nyelvű változatára négy évet kellett várni. A kötet „European Administrative Law" címen jelent meg a Sweet and Maxwell kiadó gondozásában, 1992-ben. A kötet 2. kiadása 2005-ben, annak angol nyelvü változata pedig 2006-ben látott napvilágot BadenBadenben, illetve Londonban.
} 
Program keretében az OECD/EU tehát gyakorlatilag ajánlásokatfogalmazott meg a rendszerváltó államok számára annak érdekében, hogy megfelelően felkészülhessenek az EU-csatlakozásra, illetve a közösségi/uniós jog megfelelő érvényesítésére. Az ajánlások körében - témánk szempontjából kettő bír kimagasló jelentőséggel. Az egyik a (nemzeti) közigazgatásoknak az Európai Közigazgatási Térségre való felkészítéséről, a másik pedig az Európai Közigazgatási elvekről szól. ${ }^{10} \mathrm{Az}$ első dokumentumban három alapelv kerül rögzítésre:

1. Az uniós intézmények nem helyettesíthetők a nemzeti intézményekkel, ugyanakkor együttmüködni kötelesek.

2. A nemzeti közigazgatások felelősséggel tartoznak az uniós döntések végrehajtásáért.

3. Annak ellenére, hogy az EU nem gyakorol közvetlen hatalmat a tagállamok közigazgatása fölött, mégis erős hatást gyakorol rájuk. Ezt leginkább az „eredménykötelem” kifejezés jeleníti meg leginkább. A tagállami közigazgatás legyen megbízható, átlátható és müködjön demokratikusan. ${ }^{11}$ Ezen követelményekről a 3. fejezet D. pontjában lesz részletesen szó!

Az "Európai közigazgatási alapelvekröl" szóló második dokumentumleszögezi, hogy a formálódó Európai Közigazgatási Térségben vannak olyan alapelvek, amelyeket a közösségi jog érvényesülése érdekében a tagállamok érvényesíteni kötelesek. Éppen ezért a tagjelölteknek is érvényesíteniük kell, legkésőbb a csatlakozás érdekében megvalósítandó közigazgatási reformok révén. Ezeket az alapelveket az Európai Bíróság olyanként definiálta, amelyeket minden tagállamnak alkalmaznia kell. Nevezetesen: a törvényesség elve, az arányosság elve, a jogbiztonság elve, a törvényes elvárások elve, a diszkrimináció tilalmának elve, a bírósági tárgyalás igénybevételének joga, a jogorvoslathoz való jog. Az itt felsorolt alapelvek általánosan ismert kategóriák, ezért jelentésüket nem részletezzük.

Utalunk azonban arra, hogy a Dokumentum rendszerezi is a tagállamok jogrendszereiben általánosan érvényesülő alapelveket, mégpedig a következő csoportosítás szerint: 1) megbízhatóság és kiszámíthatóság; 2) nyitottság és átláthatóság; 3) elszámoltathatóság (közfelelősség);

\footnotetext{
10 Lásd: OECD SIGMA/PUMA. Preparing Public Administrations for the European Administrative Space. SIGMA Paper. 1998. № 23. Malamint OECD SIGMA/PUMA. European Principles for Public Administration. SIGMA Paper. 1999. № 27.

11 Az Európai Közösség és a tagállamok közigazgatásai közötti-viszonylag korai-kapcsolatról lásd például Cassese S. Divided Powers: European Administration and National Administrations. The European Administration. International Institute of Administrative Sciences and European Institute of Public Administration / S. Cassese (szerk.). Brussel, 1987.
} 
4) hatékonyság és eredményesség. Ezeket az alapelveket a következő fejezetben tárgyaljuk, hiszen ezek (is) jellemzik az Európai Közigazgatási Térséget.

\section{Az Európai Közigazgatási Térség fő jellemzői}

Az EKT - illetve az Unióban fokozatosan megvalósuló közigazgatási integráció - sajátosságai tekintetében a szakirodalom viszonylag egységesen foglal állást. Az EKT sajátosságait, és fő jellemzőit az alábbiak szerint jelöljük meg.

\subsection{Politikai stabilitás, illetve a demokratikus jogállamiság követelményeinek érvényesülése}

Olyan jogrend fenntartása és múködtetése, amely biztosítja a hatalmi ágak megosztását, a demokratikus intézmény-rendszert és annak müködését, az alapvető jogok és szabadságok szabad érvényesülését, valamint a kisebbségi jogok tiszteletben tartását. Kiemelendő e körben azon uniós rendelkezés is, amely szerint az Unió az emberi méltóság tiszteletben tartásán, a szabadság, a demokrácia, az egyenlőség, a jogállamiság és az emberi jogok tiszteletben tartásán, mint értékeken alapszik. ${ }^{12}$

\subsection{Fenntartható, és a környezetet kímélö gazdasági fejlődés, amelyben meghatározó tényező a szolidaritás eszméje}

Az EUSz. 3. cikk (3) bekezdése erről a következőket írja: “Az Unió egy belső piacot hoz létre, és azon a fenntartható fejlődésért munkálkodik. A fenntartható fejlődés a belső piac kiegyensúlyozott gazdasági növekedésén, az árstabilitáson, a magas versenyképességü, teljes foglalkoztatottságon és a szociális piacgazdaságon alapszik. Mindez a környezet magas fokú védelmével párosul. Az Unió előmozdítja a tagállamok közti szolidaritást".

A szolidaritás elve elsősorban a gazdasági, társadalmi és területi kohézió, mint az egyik uniós belső politika segítségével valósul meg, az EUMSz. 174-178 cikkei alapján. Ezek értelmében az Unió - az átfogó, harmonikus fejlődés elősegítése érdekében - úgy folytatja tevékenységeit, hogy az a kohéziót, az EU összetartó erejének növekedését eredményezze. Az Unió különösen a különböző régiók fejlettségi szintje közötti egyenlötlenségek csökkentésére törekszik, továbbá kiemelt figyelmet fordít a vidéki térségekre, az ipari átalakulással érintett térségekre, a gyéren lakott és a szigeti régiókra. E célok elérését az Unió a Strukturális Alapok és az Európai Beruházási Bank forrásai, továbbá egyéb pénzeszközök felhasználásával biztosítja. A tagállamok

12 Lásd bővebben az EUSz. 2. cikkét. 
pedig - az EUMSz. 175. cikkében - kötelezettséget vállaltak arra, hogy a kohéziós célok elérése érdekében összehangolják gazdaságpolitikájukat.

\subsection{A tagállami (nemzeti) parlamentek súlyának csökkenése és a tagállami közigazgatások szerepének erösödése}

Intézményi szempontból az európai integráció nyertesei a tagállamok közigazgatási szervei, különösen a központi szervek és azon belül is a miniszterek. Nem feledhető ugyanis, hogy a minisztereket tömörítő közösségi/uniós intézmény, a Miniszterek Tanácsa hosszú időn keresztül kizárólagos jogalkotó volt, jelenleg pedig, mint Tanács, a Parlament mellett társ-jogalkotó. Ennek következtében a tagállamok nemzeti parlamentjei - a közösségi/uniós jog végrehajtása szempontjából alapvetően nem jogalkotók, hanem végrehajtók lettek. Egy szerző erről így fogalmazott 2007-ben: “Azáltal, hogy a Tanács európai szinten a központi jogalkotó szerv, és számos kompetencia a nemzeti hatáskörböl (egyúttal a nemzeti parlamentek kezéböl) európai hatáskörbe került, anélkül, hogy az Európai Parlament helyzete hasonló mértékben megerösödött volna, egyfajta jogalkotási parlamenttelenitésnek lehettünk tanúi’. ${ }^{13}$ Mindez természetesen felértékelte a tagállami miniszterek, és leértékelte a tagállami parlamentek közösségi/uniós szintű szerepét. Ezt illeti a szakirodalom „,demokratikus deficit” megnevezéssel, amelynek csökkentésére az Unió hosszú ideje törekszik. ${ }^{14}$ Például az Európai Parlament részére egyre több jogalkotási hatáskör biztosítása (1986: Egységes Európai Okmány, 1992: Maastrichti Szerződés, 1997: Amszterdami Szerződés stb.), a tagállami parlamentek uniós jogalkotásba való bevonása (EUSz. 12. cikk), az Európai Parlamentnek az Európai Bizottság létrejöttébe és megszünésébe való bevonása (EUSz. 17. és 18. cikk), stb. segítségével. Álláspontunk szerint a deficit azonban csak akkor szünne meg teljesen, ha az Európai Parlament akár a Tanáccsal együttesen - kizárólagos jogalkotóvá, a Bizottság pedig az EU kormányává válna. A fejlődés iránya kétségkívül ez, de ennek tényleges megvalósulásától még messze van az Unió. Másfelől pedig a 2008-as pénzügyi világválság, majd a 2015-től felerősödő migráció, éppen nem az integráció elmélyítésére, hanem sokkal inkább a tagállamok nemzeti intézményeinek megerősítésére ösztönözte és ösztönzi az EU tagállamait. ${ }^{15}$

13 Calliess C. Demokrácia az európai Állam- és Alkotmány-szövetségben. Jogtudományi Közlöny. 2007. November. 491. o. (kiemelés C. Calliesstől!).

14 Chiti M., Greco G. Trattato di Diritto Administrativo Europeo. Milano, 2007.

15 Lásd erről például : Forgács I. Mégsem éjjeliőr? Az európai kormányzás esélyei és a pénzügyi válság. Budapest : Osiris Kiadó, 2009. 


\subsection{Megbízható, átlátható és demokratikus közigazgatás fenntartása, illetve müködtetése}

Amegbizhatóság kapcsán abból kell kiindulni, hogy a tagállamok alapvetően külső befolyástól mentesen, szabadon szervezhetik meg közigazgatásukat, vagyis nem beszélhetünk ún. közigazgatási acquisról. Az EU számára tehát általánosságban közömbös, hogy a nemzeti közigazgatások milyen szervezeti megoldásokat és müködési módszereket alkalmaznak, milyen köztisztviselői karral rendelkeznek, a lényeg az: a közigazgatás úgy müködjön, hogy azuniós jogi aktusokban meghatározott feladatokat maradéktalanul és helyesen hajtsa végre, az Unió által kitüzött társadalmi, gazdasági és politikai célokelérése érdekében. A hangsúly tehát az uniós célok elérésén, realizálásán, azaz végeredményben az acquis communautaire hatékonyalkalmazásánés érvényesítésén van! Ennek érdekében az EU mindenekelőtt azt várja el, hogy a tagállamok közigazgatási szervezetrendszerének felépítése és működése megbízható legyen: a jogrendszerbe időben épüljenek be az uniós elöírások, azokat a különböző hatóságok ténylegesen és hatékonyan alkalmazzák is, továbbá tegyék lehetővé azok betartásának uniós szintű folyamatos ellenőrzését, és a jogviták megfelelő eszközökkel történő rendezését. A megbízhatóság magában foglalja a hatékonyság különböző elemeit: a pontosságot, a gyorsaságot, a dinamikus alkalmazkodóképességet, továbbá az EU legfőbb céljainak, a gazdasági-és pénzügyi uniónak, valamint a politikai uniónak az elérést.

Az EU elvárása az is, hogy a tagállamok közigazgatása átlátható legyen: egyértelmủ legyen az uniós intézményekkel, és mindenekelőtt az Európai Bizottsággal kapcsolatot tartó nemzetállami szervek köre, a döntési szintek és hatáskörök legyenek pontosan rögzítve és megfelelöen elhatárolva, továbbá a különböző nemzeti intézmények hatáskörei szervesen illeszkedjenek egymáshoz: ne legyen se "légüres tér", se hatásköri átfedés.

Végül: az EU elvárása az is, hogy a nemzeti közigazgatási rendszerek demokratikusan müködjenek. A demokrácia követelménye a jogállamiságot, az emberi jogok és alapvető szabadságok tiszteletben tartását, a többpártrendszert, a népuralmat, a köztisztviselők és egyéb közhatalmat gyakorlók pártsemlegességét, a jogszabályok stabilitását, és a közigazgatás kiszámítható müködését jelenti. ${ }^{16}$

\footnotetext{
16 A tagállamok eredménykötelméröl, illetve a megbízhatóság, az átláthatóság és a demokratikus müködés kritériumairól lásd : Forunier Jacques. A megbízható közigazgatás. Magyar Közigazgatás. 1997. № 10.
} 
Amennyiben az EU tagállamai nem tesznek eleget ezen uniós elvárásoknak, akkor az Európai Bizottságnak és a többi tagállamnak megvannak a jogi eszközei a kikényszerítésre, elsősorban az EUMSz. 114, 126, 258, és 259 cikk szerinti eljárásokban.

\subsection{Az európai-, illetve a jó kormányzás alapelveinek érvényesülése az egész Európai Unióban: uniós, tagállami és önkormányzati szinten egyaránt}

Itt alapvetően az Európai Bizottság által 2001-ben kiadott “Az Európai kormányzásról" címü Fehér Könyvről van szó. ${ }^{17}$ A kritikus helyzetelemzést követően a Dokumentum kimondja: ahhoz, hogy az uniós intézmények közelebb kerüljenek az uniós polgárokhoz, meg kell valósítani a "jó kormányzás" öt alapelvét: a nyitottság, a részvétel, az elszámoltathatóság, a hatékonyság és a koherencia követelményeit. A nyitottság (openness) elve azt a követelményt támasztja az intézményekkel szemben, hogy a jelenleginél sokkal nyitottabban kell működniük, fizikai értelemben is. Sőt: mindenki számára érthetővé kell tenniük, hogy mit, miért tesznek, milyen döntéseket hoznak, és ezt megfelelő nyelvezettel, közérthető formában kell kommunikálniuk. A részvétel (participation) elve a döntések megalapozottságát teremti meg, egyben növeli a polgároknak az intézményekbe vetett bizalmát, hiszen a polgároknak, valamint a különböző civil, és egyéb szervezeteknek a döntések meghozatalába való beleszólását biztosítja. Meg kell tehát szüntetni azt a helyzetet, hogy a döntéshozatal kizárólag az érintett közösségi intézményeknek a kiváltsága. Az elszámoltathatóság, illetve aszámadási kötelezettség (accountability) elve azt jelenti, hogy minden intézmény köteles egyfelől elmagyarázni és mindenkivel megértetni, hogy mit, miért tesz, másfelől pedig vállalnia is kell magatartásának, vagy mulasztásának következményeit. A hatékonyság (effectiveness) elve hármas követelményt támaszt az intézményekkel szemben. Egyrészt azt, hogy a különböző politikákat világos célok mentén, a múltbeli tapasztalatokra, és a jövőben várható hatásokra is figyelemmel, megfelelő időben kell megvalósítani (időszerüség). Másrészt azt, hogy a meghozott döntéseknek, illetve a döntések következményeinek mindig arányban kell

\footnotetext{
17 European Governance: A White Paper Commission of the European Communities. Brussels, 25.07.2001 COM (2001) 428.

Megjegyzés : kezdetben az Európai Közösség, majd az Európai Unió gyakorlatában a "fehér könyv" olyan dokumentumot jelentett és jelent, amely szerzőjének (hivatalos) javaslatát tartalmazza egy adott kérdésben. A "fehér könyv" tehát szerzőjének egy olyan politikai stratégiai koncepciója, amely a lehető legszélesebb szakértői és állampolgári konzultáció alapjaként kíván szolgálni.
} 
állniuk a kitüzött célokkal (arányosság). Harmadrészt azt, hogy a döntéseket mindig a legmegfelelöbb szinten kell meghozni (szubszidiaritás elve). A koherencia (coherence) elve az együttmüködés különböző területei közötti összhang megteremtését és érvényesítését követeli meg az intézményektöl. Világosan kell látniuk, hogy a világban bekövetkező változások egyre összetettebbek, ezért az erre adott válaszoknak is komplexnek és megfelelően összehangoltnak (koherensnek) kell lenniük.

A Bizottság Fehér Könyve kimondja azt is, hogy a ,jó kormányzás” elveit az Unió egész területén: minden uniós, továbbá tagállami hatóságnál is érvényesíteni kell. A tagállamok központi apparátusaiban és az önkormányzatoknál is. Látható, hogy itt alapvetően az uniós intézményekkel és a tagállamok nemzeti hatóságaival, mint szervezetekkel szembeni elvárásokmegfogalmazásáról van szó. Ezt azért kell hangsúlyozni, mert a tagállami közigazgatási hatóságok eljárásának egységesítéséről már az EKT következő jellemzője kapcsán ejtünk szót. ${ }^{18}$

3.6. Az eljárásrendek harmonizációja, avagy olyan eljárási szabályok és intézmények alkalmazása, amelyek biztosítják az uniós jog érvényesülését

Az utóbbi években egyre inkább egyetértés mutatkozik abban, hogy az Európai Unióban megvalósult gazdasági integrációt követnie kell a közigazgatási integrációnak is, hiszen az nem megengedhető, hogy az Unió szintjén megalkotott jogszabályokat a tagállamok huszonhét féleképpen hajtsák végre. Az Európai Közigazgatási Térségben tehát megkezdődött a tagállamok nemzeti közigazgatási szerveinek és hatósági eljárásainak egyfajta egységesitése (európaiasítása, vagy európaizálása) is.

A nyitányt az $O E C D$ korábban hivatkozott az európai közigazgatási eljárási elvekről szóló Ajánlása jelentette. ${ }^{19}$ E dokumentum - mint láttuk - négy csoportba rendezi a tagállami közigazgatási jogokkal szembeni követelményeket, az Európai Bíróság által érvényesített általános jogelvek figyelembe vételével. Ezek a következők:

a) megbízhatóság és kiszámíthatóság; b) nyitottság és átláthatóság; c) elszámoltathatóság (közfelelősség), d) hatékonyság és eredményesség. ${ }^{20}$ Ad. a) Megbizhatóság és kiszámíthatóság (reliability, predictability).

\footnotetext{
18 Megjegyezzük, hogy a "Jó kormányzás" és a "nyitottság” kifejezést az EUMSz. is használja a 15 cikkben, amikor kimondja, hogy ezen elvek érvényesülésének előmozdítása érdekében az Unió intézményei és szervei a nyitottság elvének tiszteletben tartása mellett járnak el.

19 Lásd a 10. lábjegyzetben említett második dokumentumot!

20 Ezeket az elveket elemzi a magyar szakirodalom is. Lásd például: Jenei György. Közigazgatás - menedzsment. Budapest: Századvég Kiadó, 2005. Címủ munkájának a 3.2.2. fejezetét, valamint Józsa Zoltán 3. lábjegyzetben hivatkozott tanulmányát.
} 
E két alapelv tulajdonképpen a közigazgatási szervek cselekvéseinek és döntéseinek joghoz kötöttségét, a jog uralmát, a törvényesség elve érvényesülését jelenti. A közigazgatás tehát csak és kizárólag azt teheti, amire felhatalmazása van (hatáskör elve), ha azonban van felhatalmazása, akkor cselekednie kell (hivatalból való eljárás elve). Éppen ezért az ilyen közigazgatás szükségképpen kiszámítható.

Ezen alapelvek szolgálatában azonban további princípiumok állnak. Nevezetesen: az arányosság elve, a korrekt (fair) eljárás elve, az időszerüség elve, valamint a professzionalizmus elve. Az arányosság elve azt a követelményt tartalmazza, amely szerint a döntéseknek arányosnak kell lennie a jog által meghatározott célokkal, anélkül, hogy szükségtelenül hátrányt okozna a polgároknak. A korrekt (fair) eljárás elve az ügyek részlehajlás nélküli elintézését jelenti, és kiterjed a hatóságok tájékoztatási kötelezettségére is. Az időszerüség elve azt jelenti, hogy a közigazgatási döntéseket a törvényben meghatározott határidőn belül kell meghozni, hiszen a késedelem igazságtalanságot okozhat, illetve megnehezíti a bizonyítékok beszerzését. A professzionalizmus elve a közszolgálatra vonatkozó követelmény, vagyis a köztisztviselöknek képzettnek, pártatlannak, elöítélet- mentesnek, és szakmailag függetlennek kell lenniük.

Ad. b) Nyitottság és átláthatóság (openness, transparency).

A nyitottság elve azt jelenti, hogy a közigazgatás elérhető egyfelől a külső vizsgálatok, másfelől az érintett polgárok számára. Az átláthatóság elvének érvényesülése pedig az ellenőrzés és a vizsgálat céljának megvalósulását teszi lehetővé. A két elv érvényesülése végül-is arra ad módot, hogy a közigazgatással érintettek megismerhessék jogaikat, a külső szervek pedig felülvizsgálhassák a döntések jogszerüségét. Mint ilyenek előfeltételei a törvényesség, az egyenlőség és az elszámoltathatóság elve érvényesülésének.

A nyitottság és az átláthatóság elve a közigazgatás világában két speciális célt szolgál. Egyfelől a közérdek védelmét, csökkentve a hibás döntések és a korrupció lehetőségét, másfelől pedig az egyéni jogok védelmét, azáltal, hogy elvárják a döntések racionális indoklási kötelezettségét és hozzásegítik az érdekelteket ahhoz, hogy jogorvoslati lehetőségeikkel éljenek.

A XVIII. század végéig - Svédország kivételével - általános gyakorlat volt a közigazgatásban a titkosság és a szabad mérlegelés, a diszkréció. Az ezt követő időkben a nyitottság csak azt jelentette, hogy a jogszabályok és az egyedi döntések csak akkor váltak alkalmazhatóvá, ha közölték az érdekeltekkel. Anyitottság és az átláthatóság, vagyis a nyitott kormányzás csak a XX. század vége felé vált a demokratikus jogállamiság egyik alapelvévé. 
Ad. c) Elszámoltathatóság (közfelelösség: accountability).

A közigazgatás tekintetében az elszámoltathatóság a közfelelősséggel szinonim fogalomként azt jelenti, hogy minden hatóságnak felelnie kell cselekedeteiértvagy mulasztásaiért más hatóság, bíróság, vagy a törvényhozó előtt. Másik oldalról úgy is fogalmazhatunk, hogy egyetlen hatóság sem vonhatja ki magát a külső szervek vizsgálatai alól. E felülvizsgálatok azonban minden esetben a tételes jog által rögzített szabályok betartásával valósíthatók meg, rendkívül összetett módon: a fellebbezés elbírálása a felettes hatóság által, a meghozott döntések bírósági felülvizsgálata, az ombudsman vagy az ügyész vizsgálata, vagy éppen a parlament vizsgálata. A felülvizsgálatok végső célja annak biztosítása, hogy a közigazgatás törvényesen müködjön: érvényesüljön a közérdek és érvényesüljenek az egyéni jogok is.

Az elszámoltathatóságnak nem csak közigazgatási, hanem egyéb (például: politikai, szakmai stb.) aspektusai is vannak. A közigazgatási aspektusait, illetve a közfelelösség jellemzőita szakirodalom a következők szerint összegzi:

- Elvi alapja: az eljárás jogszerúségének vizsgálata;

- Tárgya: a közigazgatási cselekvés jogszerüsége;

- Kritériuma: a hatályos jogszabályoknak való megfelelés;

- Iránya: a szerven belülre (felettes szervek) és a szerven kívülre (állampolgárok, bíróság);

- Mechanizmusa: belső és külső vizsgálatok, jogi és bírósági kontroll;

- Következményei: helyben hagyás, módosítás, megsemmisítés, szankció alkalmazása, kompenzáció. ${ }^{21}$

Ad. d) Hatékonyság és eredményesség (efficiency, effectiveness).

A hatékonysága felhasznált erőforrások és az elért eredmények közötti kedvező (jó) arányokat jelenti, és mint ilyen, a gazdasági élet kategóriája. A történelmi fejlödés során azonban az állam vált a közszolgáltatások gazdájává, így e kategória az utóbbi néhány évtizedben polgárjogot nyert a közigazgatásban is. Spanyolország esetében például ez az elv már az 1978 évi alkotmányban is megjelent, a törvényesség elve, a nyitottság elve és a pártatlanság klasszikusnak mondható közigazgatási elvei mellett.

Az eredményesség a hatékonysághoz kapcsolódó érték, amely arra utal, hogy a közigazgatás teljesítménye mennyire sikeres a törvényhozó által meghatározott célok elérésében. Mint ilyen, alapvetően a közpolitikák

21 Cendon A. Accountability in Public Administration: Conteps, Dimension, Developments. Openess and Transparency in Governance: Challenges and Opportunities / M. Kelly (szerk.). Maastricht : EIPA, 1999. 
elemzését és értékelését jelenti, illetve annak megbecsülését, hogy azok mennyiben valósultak meg a köztisztviselök tevékenységében.

A hatékonyság, minta közigazgatás működésiértéke látszólag szembenáll a közigazgatás törvény alá rendeltsége, vagyis a törvényesség elvével. Nem véletlen, hogy a közigazgatás irányítói a törvényesség elve érvényesítését gyakran hatékonyság-ellenes korlátozásnak tekintik. A feszültség, illetve konfliktus tehát kétség kívül fennáll, amit a különböző kormányok igyekeznek is kiküszöbölni. Ide sorolható példa lehet a kiszervezések megvalósítása, vagy a magánszektor bevonása a közfeladatok ellátásába (PPP-projektek).

Az OECD mellett - az Európai Unión kívüli másik európai integrációs szervezet, az 1949-ben létrehozott-Európa Tanácsis igyekezett hozzájárulni a nemzetállami közigazgatások közelítéséhez, egységesítéséhez. Az eltelt mintegy hetven év alatt, azEurópa Tanács számtalan egyezményt dolgozott ki és nyitott aláírásra meg a tagállamai előtt, továbbá számtalan ajánlást is tett a tagállamok számára. Az egyezményekközött, témánk szempontjából kiemelkedő az Emberi Jogok Európai Egyezménye, valamint a Helyi Önkormányzatok Európai Chartája. A részletek mellőzése mellett, ez utóbbi dokumentum jelentőségét abban látjuk, hogy egyfajta európai standardot rögzít arra nézve, hogy az európai államok milyen önkormányzati minimumokat kötelesek érvényesíteni.

Az Európa Tanács (Miniszteri Bizottsága) ajánlásai körében jelentős szerepet játszik a tagállami közigazgatások egységesítésében az 2007-ben kiadott, a "Jó közigazgatásról" szóló ajánlás. ${ }^{22}$ A Dokumentum abban látja a "Jó közigazgatás" garanciáját, hogy az Európa Tanács tagállamainak kormányai mind-mind támogatják a közigazgatási hatóságok szervezetének és müködésének hatékonyabbá, eredményesebbé és költségtudatosabbá tételét. Ennek érdekében az ajánlás "az eljárásrendek harmonizációját" kívánja ösztönözni oly módon, hogy a tagállamokat a mellékletben csatolt "Mintaszabályzat" követésére hívja fel. A Mintaszabályzat a következő közigazgatási (eljárási) alapelvek általános tagállami érvényesítését rögzíti, és ezzel egyfajta európai minimum eljárási standardot állapít meg:

- a közigazgatás törvénynek való alárendelése (2. cikk);

- az egyenlő bánásmód elve (3. cikk)'

- az ésszerü határidőn belüli döntéshozatal elve (7. és 13. cikk);

- a személyes adatok védelmének elve (9. cikk);

- az átláthatóság elve (10. cikk);

${ }^{22}$ Recommendation CM/REC(2007)7 of the Committee of Ministers to member states on good administration. 20 June 2007. 
- a bírósági felülvizsgálat elve (22. cikk), valamint;

- a közigazgatási jogkörben okozott kár megtérítési kötelezettségének elve (23. cikk). Látható, hogy ezek az elvek mennyire hasonlítanak, illetve esetenként egybe is esnek, az OECD korábban tárgyalt, az európai közigazgatásra vonatkozó alapelveivel. Rögzíteni kell azonban azt is, hogy a közigazgatási hatósági eljárás általános szabályairól szóló magyar törvény (a 2004. évi CLX. törvény) minden tekintetben érvényesítette ezeket az elveket. ${ }^{23} \mathrm{Az}$ e törvényt hatályon kívül helyezö, az általános közigazgatási rendtartás szabályairól szóló 2016. évi CL törvényről ugyan ez mondható el!

\subsection{Független, és a fair eljárás szabályait betartó bírósági rendszer müködtetése}

A modern államban, a parlament által meghozott törvények végrehajtásáról két szervezet-rendszer, a közigazgatás és a bíróság gondoskodik. A XVIII. és a XIX. században aztán megtörtént e két szervezetrendszer szétválasztása és önálló hatalmi ágként való müködtetése. ${ }^{24} \mathrm{E}$ folyamat nem érintette (érinti) azt a tényt, hogy a közigazgatás mellett végeredményben a bíróságok is jogalkalmazó szervek: az általános jogi normát egyedi (konkrét) esetben alkalmazzák. Természetesen más cél, más eljárási szabályok, és részben más elvek mellett.

A demokratikus jogállam alapismérve az államhatalmi ágak elválasztásának és egyensúlyának az elve. Az ilyen rendszerben nem csak a bíróságok, hanem a bírák is függetlenek, csak a törvénynek vannak alárendelve. Mindazonáltal a törvényeket ők is kötelesek betartani és betartatni, továbbá érvényesíteni a fair eljárás szabályait: az ügyfelet és az ellenérdekü felet meghallgatni, ésszerü határidőn belül dönteni, a döntést indokolni, valamint a döntés ellen jogorvoslati lehetöséget biztosítani. Az ilyen bírósági rendszerben természetesen biztosított a közigazgatási határozatok bíróság előtti megtámadásának a lehetősége is, ahogyan arra az előző jellemző kapcsán utaltunk (Lásd: az Ajánlás 22. cikkét). Akár az egységes bírósági szervezeten belül müködő rendes bíróság (például az Egyesült Királyságban), akár az azon kívül müködő közigazgatási bíróság útján (mint például Németországban).

23 Lásd erről bővebben : Fábián A. Az EU-jog és a tagállami közigazgatási eljárás kapcsolódási pontjai. Magyar közigazgatás. 2006. № 10.

24 A szervezetileg is önálló (bíróságtól független) közigazgatást először az USA hozott létre 1787-ben, majd Franciaország 1789-ben. Magyarországon erre 1869-ben, Angliában pedig 1888-ban került sor. 
3.8. Olyan közszektor fenntartása és müködtetése, amely törvényesen, a polgárok megelégedésére és hatékonyan látja el feladatait

A közszektor fogalma alatt azokat az új érték teremtéssel járó tevékenységeketértjük, amelyek közjavak előállításáhozvagy szolgáltatásához kapcsolódnak, de nem foglalják magukba az állami közhatalom birtokában ellátott tevékenységeket. A fogalom központi eleme természetesen a "közjavak" köre, ami rendszerint az alkotmányban manifesztálódik, mint alapjog. Egy adott szolgáltatást tehát az állam minősít közszolgáltatásnak, és ő maga (illetve szervezete) szabályozza, illetve nyújtja. A közjavak egy része az infrastruktúrához, más része pedig közvetlenül az ember személyéhez kapcsolódik. Az infrastrukturális közszolgáltatások a modern Európában rendszerint a következők: egészséges ivóvízzel való ellátás, közvilágítás, közutak fenntartása, köztemető fenntartása, környezetvédelem, hulladékgazdálkodás, ár-és belvíz védelem, tüzvédelem. A humán közszolgáltatások köre a modern Európában rendszerint a következő: óvodák és iskolák fenntartása, közművelődési intézmények müködtetése, egészségügyi és szociális intézmények fenntartása. ${ }^{25}$

3.9. Polgári (politikai) irányítás mellett, de politikailag semleges, és törvényes keretek között müködö fegyveres erök és rendvédelmi szervek

A demokratikus jogállam egyik ismérve az, hogy az állam külső biztonságát szavatoló fegyveres erők (a hadsereg), valamint a belső rendet biztosító rendvédelmi szervek (rendőrség, polgári védelem, tüzoltóság, büntetés-végrehajtási szervek) polgári irányítás alatt állnak. Ellenkező esetben ugyanis katonai diktatúráról van szó. A polgári irányítás azt jelenti, hogy e (közigazgatási) szerveket rendszerint a kormány irányítja, és valamelyik miniszter felügyeli. A politikailag semlegesség fogalma pedig azt jelenti, hogy a katonák és a rendvédelmi dolgozók nem folytathatnak politikai tevékenységet. Mindenkor kötelesek a jogszabályokat betartva, az aktuális politikai hatalommal szemben lojálisan tevékenykedni.

\subsection{A decentralizáció, a szubszidiaritásés a szolidaritás elvének érvényesülése}

A decentralizáció a modern állam szervezésének egyik elve. Az államhatalom központi szintről történő „leadását” jelenti az állam területi és/vagy helyi szervei részére, ésszerüségi, célszerüségi, vagy más okok miatt.

${ }_{25}$ Lásd erről bővebben például Horváth M. Tamás (szerk.). Piacok a főtéren. Helyi kormányzás és szolgáltatás-szervezés. Budapest : Magyar Közigazgatási Intézet, 2007. 
A szubszidiaritás elvének általános jelentése az, hogy egy adott kérdésben ott kell dönteni, ahol a kérdés felvetődött, hiszen ott áll rendelkezésre a legtöbb információ. Az Unió esetében ezt az elvet a Maastrichti Szerződés vezette be még 1992-ben, és az EUSz. 5. cikke erősítette meg, gyakorlatilag azonos tartalommal. E szerint azokon a területeken, amelyek nem tartoznak az Unió kizárólagos hatáskörébe, az Unió csak akkor és annyiban jár el, amikor és amennyiben a tervezett intézkedés céljait a tagállamok - tagállami intézkedésekkel - nem tudják kielégítően elérni, így azok az Unió szintjén jobban megvalósíthatók.

A szolidaritáselve kérdését a korábbiakban már érintettük. Rámutattunk arra, hogy a tagállamok egymás közötti viszonylatában értelmezendő fogalomról van szó, amelynek megvalósulását az Unió előmozdítja, illetve támogatja. Az EUSz. 3. cikk (3) bekezdése szerint ugyanis az Unió előmozdítjaa gazdasági, társadalmiés területi kohéziót, valamintatagállamok közötti szolidaritást. E cél elérését szolgálja az uniós költségvetés mintegy egyharmadának tagállamok által történő felhasználása!

Adecentralizáció, a szubszidiaritás és a szolidaritás elve érvényesülésének következtében az Unióban egyfelől megerősödtek a szubnacionális szervek (a régiók) a központi szervek terhére, másfelől pedig csökkentek a különböző régiók közötti fejlettségi különbségek. ${ }^{26}$

\subsection{Stabil, kiszámítható, hozzáértő, magasan képzett és pártatlan köztisztviselöi kar}

Az itt felsorolt közszolgálati alapelvek és értékek a jogállamiság elvéből fakadnak, és részben már érintettük is őket. Az Európai Unió intézményeiben dolgozó több ezer uniós tisztviselő számára a köztisztviselöi pálya életre szóló hivatás, és alapvető uniós érdek füződik annak stabilitásához, kiszámíthatóságához, magas szintü képzettségéhez és pártatlanságához. Mindezen követelményeket a közösségi szabályozás - lásd a több mint száz alkalommal módosított 259/68/EGK, Euratom, ESZAK tanácsi rendeletet - biztosítja, vagyis adott a karrier-rendszerű uniós életpálya. Látni kell ugyanakkor azt is, hogy az uniós jog érvényesítése, sőt, már az alkotásában való közremúködés is, nem csak az uniós tisztviselök, hanem a tagállamok köztisztviselöi számára is fontos feladat. Éppen ezért indokolt, ha rájuk is vonatkoznak azok a követelmények, amelyek irányadók az uniós tisztviselőkre. Mindezek azért rendkívül fontos körülmények, mert az uniós jog alkotása és érvényesítése során az uniós és a tagállami tisztviselők rendszeresen találkoznak,

\footnotetext{
${ }^{26}$ Lásd erről bővebben : Torma A. Idea of the European Union's organizational system. Curentul Juridic - Juridical Current. Year XII. № 2 (37). Tirgu-Mures, 2009.
} 
megismerik egymást, ami jelentősen hozzájárulhat az uniós jogalkotás és a jogalkalmazás sikeréhez. A rendszeres találkozások eredményeként az uniós tisztviselők egyre jobban megértik és elfogadják a tagállami köztisztviselőket, illetve érveiket, míg a tagállami köztisztviselők egyre jobban megértik és elfogadják az uniós tisztviselőket, illetve érveiket. Ennek következtében a tagállami köztisztviselők is egyre inkább "európaizálódnak", ezért rögzíti az EUMSz. igazgatási együttmüködésről szóló 197. cikke azt, hogy az uniós jog tagállami végrehajtása "közös érdekü” ügy.

Ugyanakkor látni kell azt is, hogy az EUMSz. 45. cikke rögzíti a munkavállalók szabad mozgásának jogát az Unióban, ami azt jelenti, hogy az uniós polgárok szabadon vállalhatnak munkát bármely más tagállamban. Ez a jog csak közrendi, közbiztonsági, vagy közegészségügyi okok miatt korlátozható. A 45. cikk (4) bekezdése azonban kimondja, hogy e rendelkezések éppen a közszolgálatban történő foglalkoztatásra nem vonatkoznak, vagyis a tagállamoknak joguk van a közszolgálatot tagállami állampolgársághoz, vagy bármely egyéb feltételhez kötni. Nyilvánvalóan azért, mert közhatalom gyakorlásáról van szó.

\section{Az Európai Közigazgatási Térség jövője}

A fent kifejtettek alapján levonható az akövetkeztetés, hogy az Európai Unió által már eddig kialakított - belső államhatárok nélküli - egységes földrajzi terület, az ugyancsak egységes európai polgárság ténye, továbbá a megvalósított egységes piac, gazdasági, pénzügyi és politikai unió, valamint az uniós jog hatékony érvényesülésének szükségességemegköveteli a tagállamok közigazgatásának további közelitését, bizonyos esetekben egységesitését is. Ez a folyamat, amelyet korábban "európaiasításnak, vagy európaizálásnak" neveztünk - hosszabb távon, tendenciáját tekintve - elvezethet a nemzetállami közigazgatások konvergenciájához, és egy valóban egységes európai közigazgatásnak a kiteljesedéséhez, kétségtelenül tovább csorbítva ezzel a tagállamok szuverenitását. E folyamatot erősíti az „európai közigazgatási jog” kialakulása és fokozatos fejlődése, amelynek tekintetében különösen az eljárási szabályok területén, valamint az uniós fejlesztési források felhasználása tekintetében történt jelentős elörelépés az egységesítésben, de nem kevésbé fontos az EUSz.-t és az EUMSz.-t létrehozó Lisszaboni Szerződés által elért eredmény sem. ${ }^{27}$

\footnotetext{
27 Az európai közigazgatásról lásd például : Ibanez Alberto J. 7. lábjegyzetben említett mủvét, továbbá Torma A. Az európai közigazgatás fogalma. Publicationes Universitatis Miskolcinensis. Sectio Juridica et Politica. Tomus XXIII/2. Miskolc University Press, 2005, továbbá Torma A. Hét tézis az EU és a tagállamok közigazgatása közötti kapcsolatról. Publicationes Universitatis Miskolcinensis. Sectio Juridica et Politica. Tomus XXIX. Miskolc University Press, 2011.
} 
Mindazonáltal látni kell azt is, hogy aLisszaboni Szerződés sem oldotta fel azt a feszültséget, amely az uniós jog hatályának egységessége és a tagállamok közigazgatásának önállósága között feszült és feszül. Márpedig ez előbb-utóbb fontos lenne, mert az EU és annak részeként az "Európai Közigazgatás, illetve az Európai Közigazgatás Jog” fejlődése egy sor új kihívás előtt áll. Utalhatunk a migrációra, a globalizációra, az energia és akörnyezetvédelmi problémákra, valamint a terrorizmus elleni harcra. ${ }^{28}$ Ezen kérdéskörök részletes tárgyalása azonban sajnos meghaladja a rendelkezésünkre álló kereteket, ezért önálló tanulmány tárgya lehet.

\section{IRODALOMJEGYZÉK}

1. Calliess C. Demokrácia az európai Állam- és Alkotmány-szövetségben. Jogtudományi Közlöny. 2007. November.

2. Cassese S. Divided Powers: European Administration and National Administrations. The European Administration. International Institute of Administrative Sciences and European Institute of Public Administration / S. Cassese (szerk.). Brussel, 1987.

3. Cendon A. Accountability in Public Administration: Conteps, Dimension, Developments. Openess and Transparency in Governance: Challenges and Opportunities / M. Kelly (szerk.). Maastricht : EIPA, 1999.

4. Chiti M., Greco G. Trattato di Diritto Administrativo Europeo. Milano, 2007.

5. Czuczai J. Közigazgatás és európai integráció. Magyar Közigazgatási Jog Különös Rész / L. Ficzere Lajos, I. Forgács (szerk.). Budapest : Osiris Kiadó, 1999.

6. D' Orta C. What for the European Administrative Space? Maastricht : EIPA, 2003.

7. European Governance: A White Paper Commission of the European Communities. Brussels. 25.07.2001. COM (2001) 428.

8. Fábián A. Az EU-jog és a tagállami közigazgatási eljárás kapcsolódási pontjai. Magyar közigazgatás. 2006. № 10.

9. Forgács I. Mégsem éjjeliőr? Az európai kormányzás esélyei és a pénzügyi válság. Budapest : Osiris Kiadó, 2009. № 10 .

10. Forunier J. A megbízható közigazgatás. Magyar Közigazgatás. 1997.

11. Gil I., Alberto J. A közösségi jog ellenőrzése és végrehajtása. Budapest : Osiris Kiadó, 2000.

\footnotetext{
28 Jürgen Schwarze (ed.). Bestand und Perspektiven des Europaischen Verwaltungsrechts. Baden-Baden : Nomos Verlag, 2008.
} 
12. Horváth M. Tamás (szerk.) Piacok a fötéren. Helyi kormányzás és szolgáltatás-szervezés. Budapest : Magyar Közigazgatási Intézet, 2007.

13. Jenei G. Közigazgatás - menedzsment. Budapest : Századvég Kiadó, 2005.

14. Józsa Z. Az európai közigazgatási tér összefüggéseiről. Magyar Közigazgatás. 2003. № 12.

15. OECD SIGMA/PUMA. European Principles for Public Administration. SIGMA Paper. 1999. № 27.

16. OECD SIGMA/PUMA. Preparing Public Administrations for the European Administrative Space. SIGMA Paper. 1998. № 23.

17. Prof. Schmidt-Assmann Eberhard. Az európai közigazgatás együttműködési és alá-fölé rendeltségi modellje. Európai Jog. 2003. № 3.

18. Recommendation CM/REC (2007) 7 of the Committee of Ministers to member states on good administration. 20 June 2007.

19. Schwarze J. (szerk.). Bestand und Perspektiven des Europaischen Verwaltungsrechts. Baden-Baden : Nomos Verlag, 2008.

20. Schwarze J. Europaisches Verwaltungsrecht. Nomos Verlagsgesellschaft. Baden-Baden, 1988.

21. Torma A. Az európai közigazgatás fogalma. Publicationes Universitatis Miskolcinensis. Sectio Juridica et Politica. Tomus XXIII/2. Miskolc University Press, 2005.

22. Torma A. Hét tézis az EU és a tagállamok közigazgatása közötti kapcsolatról. Publicationes Universitatis Miskolcinensis. Sectio Juridica et Politica. Tomus XXIX. Miskolc University Press, 2011.

23. Torma A. Idea of the European Union's organizational system. Curentul Juridic - Juridical Current. Year XII. № 2 (37). Tirgu-Mures, 2009.

\section{Information about author:}

Torma András,

$\mathrm{Ph}$. D., Professor,

Egyetemi Tanár, Rektor

Miskolci Egyetem

Miskolc-Egyetemváros, 3515, Hungary

DOI https://doi.org/10.30525/978-9934-588-43-3/1.10 